\title{
Effects of HGF and KGF gene silencing on vascular endothelial growth factor and its receptors in rat ultraviolet radiation-induced corneal neovascularization
}

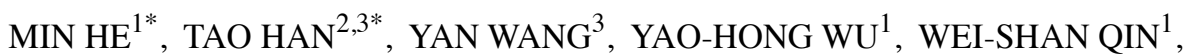 \\ LING-ZHEN DU ${ }^{1}$ and CHANG-QING ZHAO ${ }^{4}$ \\ ${ }^{1}$ Department of Ophthalmology, The Second Hospital, Shanxi Medical University, Taiyuan, Shanxi 030001; \\ ${ }^{2}$ Clinical Medical College, Second Military Medical University, Shanghai $200433 ;{ }^{3}$ Bayi Children's Hospital Affiliated to \\ PLA Army General Hospital, Beijing 100700; ${ }^{4}$ Department of Otolaryngology, The Second Hospital, \\ Shanxi Medical University, Taiyuan, Shanxi 030001, P.R. China
}

Received June 15, 2018; Accepted January 22, 2019

DOI: $10.3892 / \mathrm{ijmm} .2019 .4114$

\begin{abstract}
Hepatocyte growth factor (HGF) and keratinocyte growth factor (KGF), two paracrine growth factors, modulate corneal epithelial cell metabolism, apoptosis and survival. Vascular endothelial growth factor (VEGF) serves as a proangiogenic factor in corneal neovascularization (CNV), which is a major cause of vision impairment and corneal blindness. The aim of the present study was to evaluate the ability of HGF and KGF to influence VEGF and its receptor, kinase insert domain receptor (Flk-1) in corneal injury and $\mathrm{CNV}$ in rats induced by ultraviolet radiation (UVR). An UVR-induced corneal injury rat model was successfully established to characterize the expression patterns of KGF, HGF, VEGF and Flk-1 in corneal tissues. Corneal epithelial cells were extracted and treated with small interfering RNAs (siRNAs) targeting KGF, HGF or both (si-KGF, si-HGF or si-HGF/KGF). The effects of HGF and KGF were examined through detection of the expression of KGF, HGF, VEGF and Flk-1, and the evaluation of cell proliferation, cell cycle and cell apoptosis. The expression levels of KGF, HGF, VEGF and Flk-1 in corneal tissues were increased in the rat model. In the cell experiments, the transfection of si-HGF/KGF resulted in reductions in VEGF, Flk-1, KGF and HGF. In addition, decreased cell proliferation and elevated cell apoptosis were found in the corneal epithelial cells from the rat model following KGF and HGF gene
\end{abstract}

Correspondence to: Dr Chang-Qing Zhao, Department of Otolaryngology, The Second Hospital, Shanxi Medical University, 382 Wuyi Road, Taiyuan, Shanxi 030001, P.R. China

E-mail: zhaochangqing_zcq@163.com

*Contributed equally

Key words: hepatocyte growth factor, keratinocyte growth factor, ultraviolet radiation, cornea, vascular endothelial growth factor, neovascularization silencing. Taken together, these findings suggest that HGF and KGF gene silencing inhibits UVR-induced corneal epithelial proliferation and $\mathrm{CNV}$ and may function as novel targets for corneal wound healing.

\section{Introduction}

The cornea has the physiological capacity to absorb the majority of ultraviolet radiation (UVR), and protects the inner eye from ultraviolet (UV)-induced oxidative damaging effects (1). Corneal injury can produce photophobia, an aversive sensitivity to light, and even blindness (2), and corneal injury remains a major reason for consultations in ophthalmology clinics worldwide (3). The common pathological characteristics of corneal injury include inflammatory factor activation, vascular endothelial cell or inflammatory cell infiltration into lesions, corneal edema, corneal neovascularization $(\mathrm{CNV})$ and scar formation (4). Photokeratitis can be caused by UV, and a model of photokeratitis can be established with $400 \mathrm{~mJ} / \mathrm{cm}^{2}$ of UVB irradiation to mice corneas (5). Patients with UV-induced photokeratitis exhibit promoted apoptosis of corneal cells due to inflammatory response, induction of reactive oxygen species (ROS), and damage to the cell membrane and deoxyribonucleic acid (DNA) (6). Treatment, including the topical administration of peroxiredoxin- 6 , has been reported to promote recovery from UV-induced corneal injury after 14 weeks (7). Chemical burns and exposure to UVB lead to corneal injury, which can be aggravated by inflammatory responses, oxidative stress and neovascularization, resulting in blindness $(8,9)$. Exposure to UV lasers can result in pathology to the cornea, lens or retina of the primate eye (10). Specifically, irradiation of the eyes with UV causes serious enzymatic disturbances and inflammatory reactions in the cornea (7). Chronic exposure to UVR causes damage to the anterior pole of the eye, such as pterygium or photokeratitis, which is accompanied by several corneal disorders, including inflammatory infiltration and CNV (11). In the last decade, several aspects of the wound healing process in different regions of the cornea have been elucidated, and therapeutic approaches have emerged with novel markers identified 
and novel treatment options, including gene and microRNA therapies that have been tested in experimental systems $(12,13)$. For example, hepatocyte growth factor (HGF), keratinocyte growth factor (KGF) and their receptors have been associated with wound healing in the cornea (14).

HGF comprises an $\alpha$-chain and a $\beta$-chain, which contain four kringle domains and a serine protease-like structure, respectively (15); these structures induce a three-phase response, resulting in the formation of branched tubular structures in epithelial cells (16). In addition, KGF, a member of the fibroblast growth factor family, is a human mitogen that is specific for epithelial cells and functions as a stromal mediator of epithelial cell proliferation (17). KGF is secreted by stromal cells in a variety of tissues, including the cornea, skin, prostate and mammary gland (18). These two paracrine growth factors, namely, HGF and KGF, influence corneal epithelial cell metabolism (19). They have specific effects on corneal epithelial cell cycle regulatory proteins; for example, HGF can rescue epithelial cells from apoptosis and KGF promotes cell survival in corneal epithelial cells (20). CNV is a major cause of vision impairment and corneal blindness (21) and may result from a disrupted balance between the upregulation of angiogenic factors and the downregulation of antiangiogenic factors (13). Additionally, vascular endothelial growth factor (VEGF) is a multifunctional cytokine that is overexpressed in several transplantable and autochthonous tumors, in healing wounds and in chronic inflammatory disorders, including psoriasis and rheumatoid arthritis (22). It is well established that CNV is tightly regulated by a dynamic, natural equilibrium between local proangiogenic factors, including VEGF, and antiangiogenic molecules (7). The present study was designed to thoroughly examine the effects of HGF and KGF gene silencing on VEGF and its receptors on UVR-induced CNV in rats.

As stated above, factors causing corneal injury include infection, physical injury, chemistry and UVR. However, the repair of corneal injury and the mechanism of neovascularization remain to be elucidated. Furthermore, in addition to ozone depletion and environmental disruption, UVR has increased, causing an increase in the number of patients suffering from UVR-induced corneal injury (23). Therefore, the present study examines the effects of $\mathrm{HGF} / \mathrm{KGF}$ on neovascularization in the rat model of UVR-induced corneal injury.

\section{Materials and methods}

Ethics statement. This study protocol was approved by the Animal Ethics Committee of the Second Hospital, Shanxi Medical University (Taiyuan, China). All animal experiments were performed in line with the approval of the Guide for the Care and Use of Laboratory Animal by International Committees. Additionally, the implementation of humane endpoints was in compliance with the guideline of assessment for humane endpoints in animal experiments (RB/T 173-2018). The humane endpoints were met when the rats presented with massive hemorrhage or other hemorrhage, blindness, dyspnea or impending death, or when the rats failed to develop the characteristics of the model during the experiments.

Study subjects. A total of 46 clean, 6-week-old male Wistar rats weighing 180-220 $\mathrm{g}$ (provided by the Laboratory Animal
Center of Sun Yat-sen University of Medical Sciences, Guangzhou, China), weighing 180-220 g, were used in the present study. The rats were fed at $22-24^{\circ} \mathrm{C}$, with a humidity of 50-60\%, with an alternating 12-h light:dark cycle, and with free access to water and food. The rats were randomly classified into normal and model groups ( $n=23$ in each group).

UVR-induced corneal injury model construction. The right eyes collected from the rats in the model group were used for the experiments. The UVR-induced corneal injury model was constructed using an UVR exposure method, as previously described (7,24). In detail, the rats received an intraperitoneal injection of $10 \mathrm{~g} / \mathrm{l}$ pentobarbital sodium $(40 \mathrm{mg} / \mathrm{kg})$ and were subjected to pupillary dilation using a compound tropicamide eye drop after being anesthetized. The eyes were placed under a UV lamp with a wavelength of $280 \mathrm{~nm}$ for $20 \mathrm{~min}$ for 4 consecutive days and a cumulative radiation dose of $9 \mathrm{~kJ} / \mathrm{m}^{2}$ based on the UV light meter. After the 2nd, 4th, and 6th day of model construction, corneal damage in the rats was examined using a routine slit-lamp, and a slit-lamp microscope was used to observe the corneal damage during the modeling. Prior to the observation, the rats were anesthetized and were subjected to pupillary dilation using the tropicamide eye drops in order to record the corneal damage and the corneal neovascularization. Images were captured and recorded, and the corneas were scored in accordance with the Dickey grading criteria (Table I) (25).

Hematoxylin and eosin $(H \& E)$ staining. Corneal damage in the rats was examined under the slit-lamp microscope. On the 6th day following exposure to UVR, the corneas from the normal rats and model rats were collected and sectioned to observe the pathological changes. The rats weighted 220-260 g at the time of sacrifice. The rats in each group were anesthetized through intraperitoneal injection of $2 \%$ pentobarbital sodium (30 mg/kg) and then sacrificed by cervical dislocation. The cornea tissues were immediately collected using ophthalmic scissors. The tissues then were fixed in Bouin solution for $24 \mathrm{~h}$ and were dehydrated, cleared, embedded with paraffin and cut into $4-\mu \mathrm{m}$ sections. The sections were deparaffinized, dehydrated, conventionally treated with H\&E staining, dehydrated by gradient alcohol, cleared with xylene, and mounted with neutral balsam. Finally, the sections were observed and images were captured under an optical microscope.

Lentiviral vector construction. The primers and meaningless siRNA sequences (Table II) of KGF-siRNA and HGF-siRNA were designed according to the GeneBank gene sequence using online design software (BLOCK-iT ${ }^{\mathrm{TM}}$ RNAi Designer; http://rnaidesigner.invitrogen.com/rnaiexpress/) from Invitrogen; Thermo Fisher Scientific, Inc. (Waltham, MA, USA). The primers and sequences were then connected with the plasmid pcDNATM6.2-GM/EmGFP-siRNA (Invitrogen; Thermo Fisher Scientific, Inc.), and these were added into competent Escherichia coli TG1 bacteria (cat. no. ZY12, Shanghai Zeye Biotech Co., Ltd., Shanghai, China), and incubated at $37^{\circ} \mathrm{C}$ for $90 \mathrm{~min}$ and incubated at $37^{\circ} \mathrm{C}$ for $12 \mathrm{~h}$. Sequencing and screening was conducted by Sangon Biotech Co., Ltd. (Shanghai, China) to construct the lentiviral vectors pcDNATM6.2-GM/EmGFP-negative-siRNA (non-targeting 
Table I. Dickey grading criteria for edematous corneal opacity.

\begin{tabular}{llc}
\hline Grading & \multicolumn{1}{c}{ Surface characteristics } & Points \\
\hline 0 stage & Transparent cornea & 0 \\
I stage & Mild corneal hazy opacities & 1 \\
II stage & Corneal opacities but anterior chamber clearly visible & 2 \\
III stage & More corneal opacities and anterior chamber less visible & 3 \\
IV stage & Marked corneal opacities and anterior chamber not visible & 4 \\
\hline
\end{tabular}

Table II. siRNA sequences for lentiviral vector construction.

\begin{tabular}{ll}
\hline siRNA & \multicolumn{1}{c}{ Sequence (5'-3') } \\
\hline HGF-siRNA & CAAGTGCAGTAACATATCTCCTGAA \\
KGF-siRNA & CGGAACTCTTGTGTACCCAGCTGTT \\
NC-siRNA & ACGTCTCGTGTATCCACCGTAAGCC \\
\hline
\end{tabular}

siRNA, small interfering RNA; HGF, hepatocyte growth factor; KGF, keratinocyte growth factor; $\mathrm{NC}$, negative control.

scramble sequence), pcDNATM6.2-GM/EmGFP-KGF-siRNA (KGF-siRNA; siRNA targeting KGF) and pcDNATM6.2-GM/ EmGFP-HGF-siRNA (HGF-siRNA; siRNA targeting HGF) (Biologic Wind Company, Shanghai, China). The blank vector was pcDNATM6.2-GM/EmGFP-siRNA. The pcD-NATM6.2GM/EmGFP-HGF-siRNA and pcDNATM6.2-GM/EmGFPKGF-siRNA vectors were treated by double enzyme digestion with BamHII and XhoI (Santa Cruz Biotechnology, Inc., Dallas TX, USA) to obtain the inserted fragments and vector backbones, which were then connected with T4 ligase, sequenced and identified to obtain the lentiviral vector pcDNATM6.2-GM/EmGFP-KGF- HGF-siRNA (KGF- HGFsiRNA).

Cell culture, transfection and grouping. The rats from the normal and model groups were sacrificed, and the corneal tissues were immediately extracted using ophthalmic scissors. Briefly, the rat eyes were sterilized using $75 \%$ ethyl alcohol and added to $1.5-\mathrm{ml}$ centrifuge tubes containing sterile phosphate-buffered saline (PBS) and 1\% (v/v) $100 \mathrm{U} / \mathrm{ml}$ penicillin and streptomycin $100 \mu \mathrm{g} / \mathrm{ml}$ (Sangon Biotech Co., Ltd.), followed by at least three washes. Excess sclera was removed with the use of sterile ophthalmic scissors following collection of the corneas along the corneal limbal rims. Under a stereoscopic dissection microscope (Carl Zeiss GmbH, Oberkochen, Germany), the corneal endothelia and stromata were cautiously stripped off with sterile surgical forceps (thin-tipped). Finally, the residual corneal stroma was again removed, gradually, following which the straticulate epithelia were inoculated into 12-well plates (26). The corneal epithelial cells were separated and cultured in Roswell Park Memorial Institute (RPMI)-1640 medium (Gibco; Thermo Fisher Scientific, Inc.), containing 10\% fetal bovine serum (FBS; HyClone; GE Healthcare Life Sciences, Logan, UT, USA), at $37^{\circ} \mathrm{C}$ with $5 \% \mathrm{CO}_{2}$. The cells were treated with $0.25 \%$ trypsin
(Gibco; Thermo Fisher Scientific, Inc.) and were triturated using the RPMI-1640 medium containing 10\% FBS to prepare the single cell suspension, followed by conventional subculture. Cells at the logarithmic growth phase were extracted for the subsequent experiment.

The corneal epithelial cells from rats in the normal and model groups were collected and assigned to a normal group (non-UVR-exposed corneal epithelial cells from normal rats without any treatment); blank group (corneal epithelial cells from model rats transfected with pcDNATM6.2GM/EmGFP-siRNA), negative control (NC) group (corneal epithelial cells from the model rats transfected with pcDNATM6.2-GM/EmGFP-negative-siRNA); si-HGF/KGF group (HGF and KGF double gene silencing, corneal epithelial cells from the model rats transfected with HGF-KGF-siRNA); si-HGF group (HGF gene silencing, corneal epithelial cells from the model rats transfected with HGF-siRNA) and si-KGF group (KGF gene silencing, corneal epithelial cells from the model rats transfected with KGF-siRNA). Only the UVR-exposed corneal tissues were infected with lentivirus vectors. The healthy corneal tissues, together with UVR-damaged corneal tissues infected with or without the lentivirus NC vector, were set as controls to determine the biological function of HGF/KGF in UVR-damaged corneal tissues. The transfection procedures were as follows: Cells were subcultured on the day prior to the transfection and were inoculated into 6-well plates, with $1 \times 10^{6}$ cells in each well. When the cells reached a confluence of $70-80 \%$, they were transfected. The cells were transfected using Lipofectamine 2000 reagent, according to the manufacturer's protocol (cat. no. 11668-019, Invitrogen; Thermo Fisher Scientific, Inc.). A total of $250 \mu \mathrm{l}$ Opti-MEM serum-free medium (cat. no. 51985042, Gibco; Thermo Fisher Scientific, Inc.) was used to dilute $100 \mathrm{ng}$ of pcDNATM6.2-GM/EmGFP-siRNA, pcDNATM6.2-GM/EmGFP-negative-siRNA, HGF-KGFsiRNA, KGF-siRNA and HGF-siRNA lentiviral vectors (final concentration of $50 \mathrm{~nm}$ ), and they were gently mixed and incubated at room temperate for $5 \mathrm{~min}$. Another $250 \mu \mathrm{l}$ Opti-MEM serum-free medium was used to dilute the Lipofectamine 2000 $(5 \mu \mathrm{l})$, and this was gently mixed and incubated at room temperate for $5 \mathrm{~min}$. The two abovementioned dilutions were mixed and incubated at room temperate for $20 \mathrm{~min}$, followed by their addition into the cell culture wells. The transfected cells were further incubated in a $5 \% \mathrm{CO}_{2}$ incubator at $37^{\circ} \mathrm{C}$. The complete medium was replaced after 6-8 $\mathrm{h}$, and the subsequent experiments were conducted after $24-48 \mathrm{~h}$.

Reverse transcription-quantitative polymerase chain reaction $(R T-q P C R)$ analysis. The corneas from rats in the normal and 
model groups were placed in liquid nitrogen and were then ground into a uniform powder. The total RNA was extracted using the TRIzol reagent kit (cat. no. 15596-018, Invitrogen; Thermo Fisher Scientific, Inc.) and the concentration and purity of the RNA were determined. According to the instructions in the Primescript ${ }^{\mathrm{TM}}$ RT reagent kit (cat. no. RRO37A, Takara Biotechnology Co., Ltd., Dalian, China), the RNA was reverse transcribed into complementary DNA (cDNA), with a total volume of $25 \mu \mathrm{l}$. The cDNA was diluted with $65 \mu \mathrm{l}$ diethyl pyrocarbonate and was fully mixed. RT-qPCR analysis was conducted using the cDNA according to the instructions in the SYBR ${ }^{\circledR}$ Premix Ex Taq ${ }^{\mathrm{TM}}$ II kit (Takara Biotechnology Co., Ltd.). The reaction system (50 $\mu \mathrm{l})$ included $25 \mu \mathrm{l}$ of SYBR Premix Ex Taq II (2X), $2 \mu \mathrm{l}$ of PCR forward primers, $2 \mu \mathrm{l}$ of PCR reverse primers, $1 \mu 1$ of ROX Reference dye (50X), $4 \mu 1$ of DNA template and $16 \mu \mathrm{l}$ of $\mathrm{d}_{2} \mathrm{O}$. The RT-qPCR procedure was performed using the ABI PRISM ${ }^{\circledR} 7300$ system (Applied Biosystems; Thermo Fisher Scientific, Inc.). The reaction conditions were as follows: Predenaturation at $95^{\circ} \mathrm{C}$ for $4 \mathrm{~min}$; 40 cycles of denaturation at $94^{\circ} \mathrm{C}$ for $30 \mathrm{sec}$, annealing at $58^{\circ} \mathrm{C}$ for $30 \mathrm{sec}$ and extension at $72^{\circ} \mathrm{C}$ for $1 \mathrm{~min}$; with extension at $72^{\circ} \mathrm{C}$ for $7 \mathrm{~min}$ after the final cycle. The $\beta$-actin gene was used as the internal reference, and all primers (Table III) were designed and synthesized by Wuhan Bojie Biological Engineering Company (Wuhan, China). The relative expression of the target genes was calculated using the $2^{-\Delta \Delta \mathrm{Cq}}$ method. The formula was as follows: $\Delta \Delta \mathrm{Cq}=\Delta \mathrm{Cq}$ experimental group $-\Delta \mathrm{Cq}$ control group and $\Delta \mathrm{Cq}=\mathrm{Cq}$ target gene $-\mathrm{Cq} \beta_{\text {-actin. }} . \mathrm{Cq}$ represents the number of amplification cycles when the real-time fluorescence intensity reached a set threshold value, and amplification was performed in logarithmically growing cells at the same time (27). Tissue samples from 10 rats were collected from each group, and the experiment was repeated three times. The above method was also used for the cell experiments.

Western blot analysis. The corneas from rats in the normal and model groups were placed in liquid nitrogen, were ground into a uniform powder, added to lysis buffer (cat. no. C0481, Sigma-Aldrich; Merck KGaA, Darmstadt, Germany) and centrifuged $(30,237 \mathrm{x} \mathrm{g})$ at $4^{\circ} \mathrm{C}$ for $15 \mathrm{~min}$; the supernatant obtained was saved for later use. The bicinchoninic acid assay was conducted for protein quantitation. The $10 \%$ sodium dodecyl sulfate (SDS) separation gel and spacer gel were prepared, and the total protein $(40 \mu \mathrm{g})$ and SDS sample buffer were mixed and denatured following boiling at $100^{\circ} \mathrm{C}$ for 5 min. Following ice-bath treatment and centrifugation at $179 \mathrm{x} g$ for $5 \mathrm{~min}$ at room temperature, each lane was loaded with the samples for electrophoresis separation. The proteins in the gel were transferred onto a nitrocellulose membrane, which was blocked with $5 \%$ skim milk at $4^{\circ} \mathrm{C}$ overnight. The membrane was then incubated overnight at $4^{\circ} \mathrm{C}$ with primary antibodies against KGF (1:1,000, cat. no. ab131162), HGF (1:5,000, cat. no. ab178395), VEGF (1:1,000, cat. no. ab32152), kinase insert domain receptor (Flk-1; 1:1,000, cat. no. ab11939) and $\beta$-actin (1:1,000, cat. no. ab8277). All antibodies were from Abcam (Cambridge, MA, USA). Subsequently, the membrane was rinsed with Tris-buffered saline with Tween-20 (TBST) three times ( $5 \mathrm{~min}$ each) at room temperature. The membrane was then incubated with a secondary antibody horseradish peroxidase-labeled $\operatorname{IgG}(1: 500)$ at $37^{\circ} \mathrm{C}$ for $1 \mathrm{~h}$. The membrane
Table III. Primer sequences for reverse transcription-quantitative polymerase chain reaction analysis.

\begin{tabular}{ll}
\hline Gene & \multicolumn{1}{c}{ Primer sequence (5'-3') } \\
\hline VEGF & F: TGCACCCACGACAGAAGGGGA \\
& R: TCACCGCCTTGGCTTGTCACAT \\
Flk-1 & F: TAGCGGGATGAAATCTTTGG \\
& R: GACTGTGCATGTCAGCGTCT \\
HGF & F: CTGCTCTATAATGCGCAAATGG \\
& R: TGGACTCATGTCATTGCAAGCT \\
KGF & F: GCACTACACTAATGCAC \\
& R: AAAGAAATCTCCCTGCTGG \\
$\beta$-actin & F: CACCCGCGAGTACAACCTTC \\
& R: CCCATACCCACCATCACACC \\
\hline
\end{tabular}

F, forward; R, reverse; VEGF, vascular endothelial growth factor; Flk-1, kinase insert domain receptor; HGF, hepatocyte growth factor; $\mathrm{KGF}$, keratinocyte growth factor.

was rinsed in PBS three times (5 min each). The reaction membrane was completely immersed in an electrochemiluminescence solution, developed in a dark room and images were captured. $\beta$-actin was considered the internal reference. The ratio of the target band to the internal reference band was used to determine the relative protein level. Tissue samples from 10 rats were collected from each group. The experiment was repeated three times. The above method was also used for the cell experiments, which were performed following $48 \mathrm{~h}$ of transfection.

3-(4,5-dimethylthiazol-2-yl)-2,5-diphenyl tetrazolium bromide (MTT) assay. Following transfection for $48 \mathrm{~h}, 100 \mu \mathrm{l}$ of the cell suspension in each group was inoculated into 96-well plates $\left(2 \times 10^{3}\right.$ cells per well) and was incubated with $5 \% \mathrm{CO}_{2}$ at $37^{\circ} \mathrm{C}$. The four-time points were set as $0,24,48$ and $72 \mathrm{~h}$. At $4 \mathrm{~h}$ prior to culture ending, $20 \mu \mathrm{l}$ of MTT $(5 \mathrm{mg} / \mathrm{ml})$ solution was added in each well. After $4 \mathrm{~h}$, the supernatant was discarded. Dimethyl sulfoxide (100 $\mu \mathrm{l}$ in each well) was dropped into the wells, and were shaken for $5 \mathrm{~min}$. The optical density (OD) value of each well was determined using a microplate reader (Multiskan FC, Thermo Fisher Scientific, Inc.) at a wavelength of $590 \mathrm{~nm}$. A total of 10 parallel wells were set in each group, and the mean value was obtained. The experiment was repeated three times and was performed by the same individual. Cell viability curves were drawn with the time point as the abscissa and the OD value as the ordinate.

Flow cytometry. Following transfection of the cells in each group for $48 \mathrm{~h}$, the supernatant was discarded, and the cells were washed once with a PBS balanced salt solution. The cells were treated with $0.25 \%$ trypsin solution. The digestion solution was discarded when the cells were observed to shrink and became round under the microscope. Medium containing serum was used to terminate the digestion. The cells were separated from the well following trituration, and made into a mixed cell suspension followed by centrifugation 
at $179 \mathrm{x} \mathrm{g}$ for $5 \mathrm{~min}$ at room temperature; the supernatant was discarded. The cells were rinsed with PBS twice, fixed in precooled $70 \%$ ethanol for $30 \mathrm{~min}$, and were then centrifuged at $179 \times \mathrm{g}$ for $5 \mathrm{~min}$ at room temperature and collected. Following this, the cells were washed with PBS, stained with $1 \%$ propidium iodide (PI) containing RNase for $30 \mathrm{~min}$ and washed twice with PBS to wash away the PI. The volume of the cells was adjusted to $1 \mathrm{ml}$ using a PBS balanced salt solution. A BD-Aria FACSCalibur flow cytometer (FACSCalibur; Beckman Coulter, Inc., Brea, CA, USA) was used to detect the cell cycle (28). Tissue samples from 10 rats in each group were detected, and the experiment was repeated three times.

Following transfection for $48 \mathrm{~h}$, the cells were treated with ethylenediaminetetraacetic acid-free trypsin and were collected in a flow tube. Following centrifugation, the supernatant was discarded. The cells were rinsed in cold PBS three times, and the supernatant was discarded following centrifugation at $179 \mathrm{x}$ g for $5 \mathrm{~min}$ at room temperature. According to the instructions in the Annexin V-fluorescein isothiocyanate (FITC)/PI double staining cell apoptosis assay kit (cat. no. C1065, Beyotime Institute of Biotechnology, Shanghai, China), Annexin V-FITC, PI and HEPES buffer (1:2:50) were formulated to make the Annexin V-FITC/PI double staining solution. The cells were resuspended (100 $\mu \mathrm{l}$ staining solution for $1 \times 10^{6}$ cells), shaken, mixed and incubated at room temperate for $15 \mathrm{~min}$. Subsequently, the cells were added to HEPES buffer $(1 \mathrm{ml})$ and were oscillated to mix. A flow cytometer was used to record the apoptosis conditions at a wavelength at $488 \mathrm{~nm}$. Band pass filters at 525 and $620 \mathrm{~nm}$ were used to detect the FITC and PI fluorescence, respectively. Tissue samples from 10 rats were collected in each group, and the experiment was repeated three times. The healthy living cells in the lower left quadrant of the scatter plots are expressed as (FITC $\left./ \mathrm{PI}^{-}\right)$. The mechanically damaged cells in the upper left quadrant are expressed as $\left(\mathrm{FITC}^{-} / \mathrm{PI}^{+}\right)$. The early apoptotic cells in the lower right quadrant are expressed as (FITC $\left.{ }^{+} / \mathrm{PI}^{-}\right)$. The late apoptotic and necrotic cells in the upper right quadrant are expressed as $\left(\mathrm{FITC}^{+} / \mathrm{PI}^{+}\right)$. Apoptotic rate $=$percentage of early apoptotic cells + percentage of late apoptotic cells.

Statistical analysis. All data from the experiments were analyzed using SPSS version 22.0 software (IBM Corp., Armonk, NY, USA). The count data (success rate of model establishment) are expressed as the percentage. The measurement data are presented as the mean \pm standard deviation. Comparisons between two groups were measured using a paired t-test and unpaired Student's t-test. Comparisons among multiple groups were conducted by one-way analysis of variance, and Tukey's post hoc test was used. $\mathrm{P}<0.05$ was considered to indicate a statistically significant difference.

\section{Results}

Successful establishment of the rat model of UVR-induced corneal injury. A model of corneal injury induced by UVR was established. Following UVR exposure, the injuries during modeling of the rats were observed under a slit-lamp microscope on the $2 \mathrm{nd}$, 4 th and 6 th days. Based on the state of injury, the rats in the model group were scored as grade IV using the Dickey edematous corneal opacity grading
Table IV. Corneal opacity scores in the normal rats and model rats of ultraviolet radiation-induced corneal injury.

Group

Corneal opacity

Normal 0

Model

$3.62 \pm 0.31^{\mathrm{a}}$

Data are presented as the mean \pm standard deviation $(\mathrm{n}=23) .{ }^{\mathrm{a}} \mathrm{P}<0.05$, vs. normal group.

standard, suggesting successful modeling, and the success rate was $100 \%$. The results from the corneas observed under the slit-lamp microscope (Fig. 1A and B, Table IV) showed that the normal cornea was completely transparent and without vessels, and the surrounding vessels were mainly on the edge of the cornea and formed the vessel net. Neovascularization was not apparent in the model group (Fig. 1B) as serious corneal opacity was observed (degree IV pathology), and the anterior chamber was not observed. Cataract induced by chronic UVR may be a major factor accounting for this phenomenon (29). On the 6th day after UVR exposure, serious corneal opacities were visible in the model rats and the opacity reached degree IV pathology, which demonstrated successful modeling $(23,30)$. Therefore, the model of rats with corneal injury induced by UVR was successfully established.

Pathological changes in the corneal tissues of model rats. H\&E staining can be used to determine whether UV induces corneal epithelial cell proliferation, during which corneal cell thickness is reduced $(5,6,31)$. In the present study, $H \& E$ staining was used to observe pathological changes in the corneal tissues. The results showed that the normal corneal epithelium exhibited between five and six layers of regularly arranged epithelia, which had a clear boundary with the Bowman's layer. The Bowman's layer was uniform in thickness, and the stromal layer showed an orderly arranged collagenous fiber bundle. In the model group, the rats had severe corneal epithelial cell hyperplasia and edema (Fig. 2A). In addition, the immunohistochemistry (Fig. 2B) used to examine the expression of platelet endothelial cell adhesion molecule-1 (CD31; an angiogenesis marker) suggested that, compared with the normal group, the model group had upregulated expression of CD31. These data showed abnormal morphology of the corneal tissues and CNV in the model rats.

mRNA and protein levels of KGF and HGF are high in the corneal epithelial tissues of model rats. Subsequently, the mRNA and protein levels of KGF, HGF, VEGF and Flk-1 were measured by RT-qPCR and western blot analyses. As shown in Fig. 3A-C, compared with the normal group, the mRNA and protein levels of the aforementioned genes in the model group were significantly increased $(\mathrm{P}<0.05)$, which revealed that the model rats had high expression levels of KGF and HGF.

Successful transfer of vectors and sequences into the corneal epithelial cells of the model rats. A fluorescence microscope was then used to examine the expression of the vectors 
A

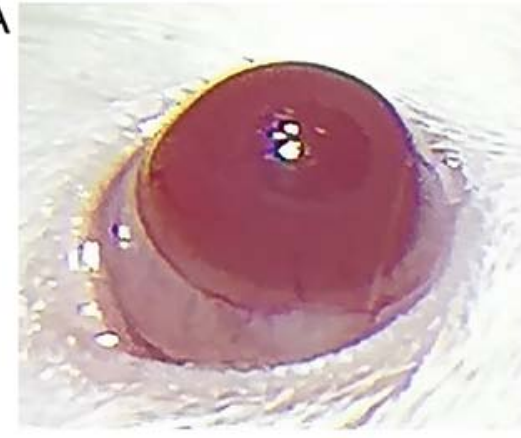

B

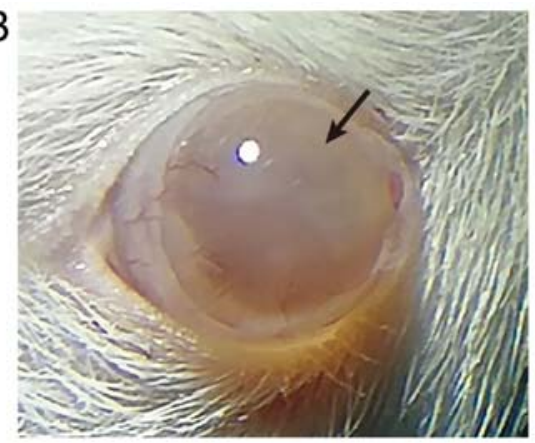

Figure 1. Successful establishment of a rat model of UVR-induced corneal injury as observed using a slit-lamp microscope. Corneal damage during modeling was observed using a slit-lamp microscope on the 6th day following exposure to UVR. (A) Cornea of a rat in the normal group. (B) Cornea of a rat in the model group; the black arrow points to corneal opacities. UVR, ultraviolet radiation.
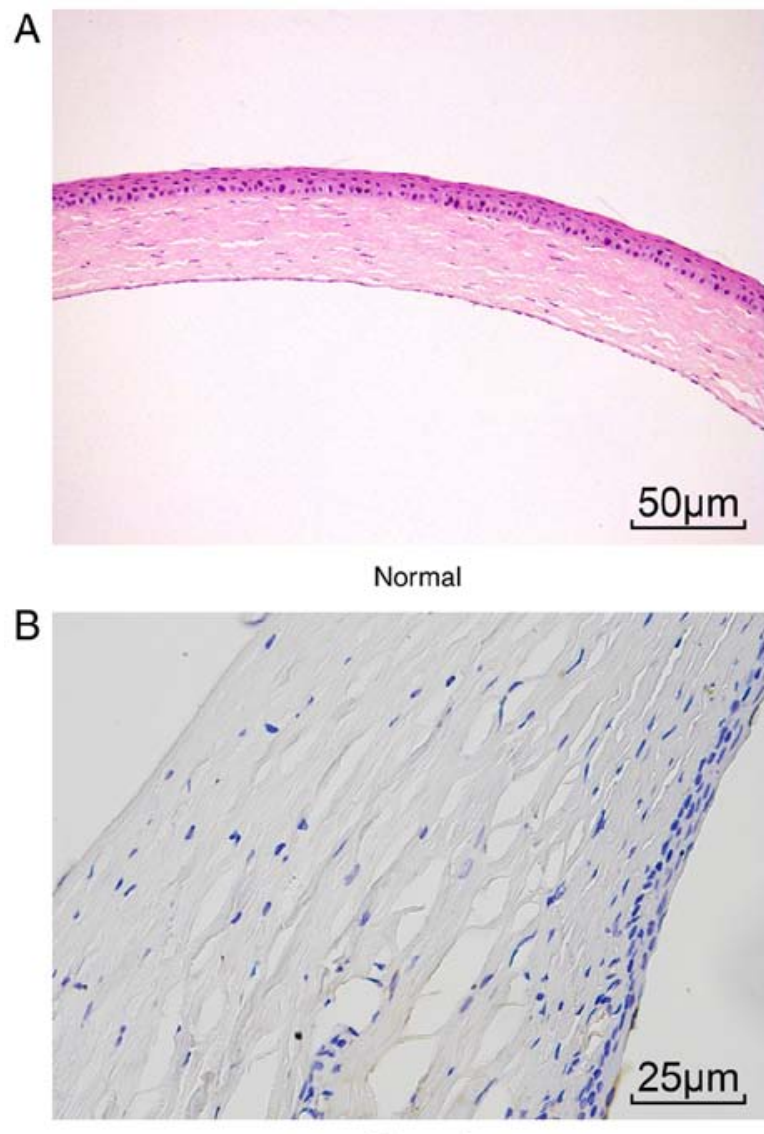

Normal

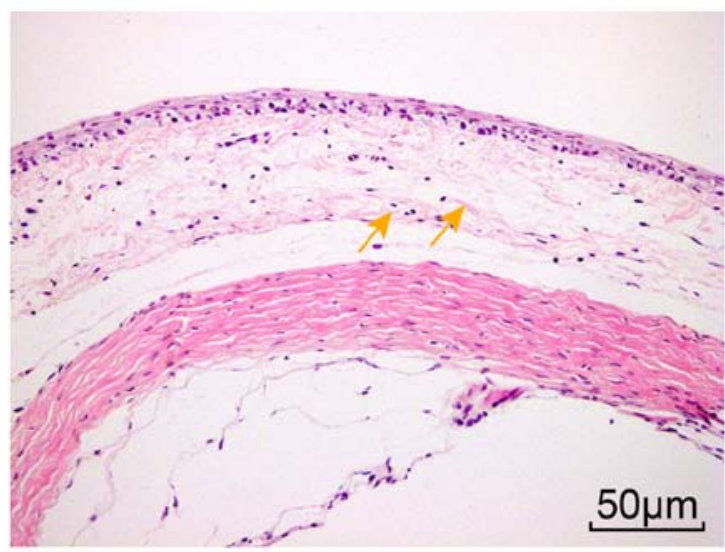

Model

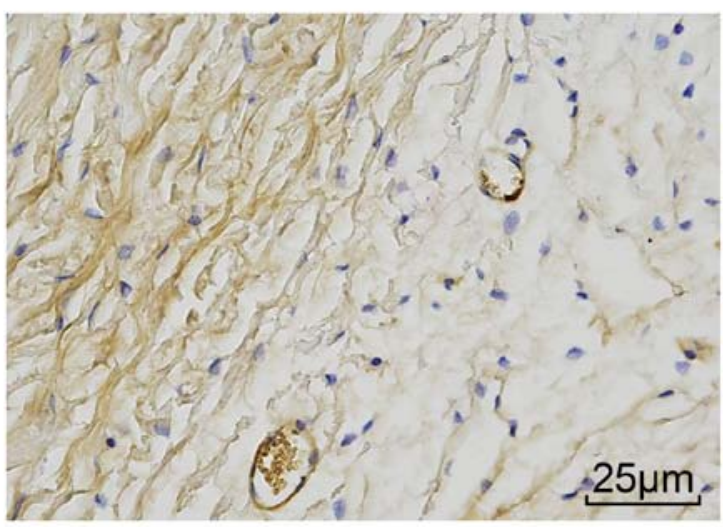

Model

Figure 2. Model rats exhibit an abnormal morphology and CNV in the corneal tissues and a high expression of CD31 on the 6th day following UVR exposure. (A) H\&E staining results of corneal tissues in the normal and model groups on the 6th day following exposure to UVR. The yellow arrows show hyperplastic and larger corneal epithelial cells; scale bar, $50 \mu \mathrm{m}$. (B) Expression of CD31 in the normal and model rats, as detected by immunohistochemistry on the 6th day following exposure to UVR; scale bar, $25 \mu \mathrm{m}$. CNV, corneal neovascularization; H\&E, hematoxylin and eosin; UVR, ultraviolet radiation; CD31, platelet endothelial cell adhesion molecule-1.

and sequences. Following cell transfection, the cells in the normal group showed no green fluorescence. By contrast, significant green fluorescence was present in the blank, NC, si-KGF, si-HGF and si-HGF/KGF groups (expression rate reaching 80\%; Fig. 4A and $\mathrm{B}$ ). This demonstrated that the lentiviral vectors pcDNATM6.2-GM/EmGFP-KGF-HGF-siRNA, pcDNATM6.2-GM/EmGFP-KGF-siRNA, pcDNATM6.2GM/EmHGF-siRNA, pcDNATM6.2-GM/EmGFP-siRNA and pcDNATM6.2-GM/EmGFP-negative-siRNA were all introduced into the corneal epithelial cells and were effectively expressed in the cells.

mRNA and protein levels of KGF, HGF, VEGF and Flk-1 are decreased by si-HGF/KGF. To investigate the mRNA and protein levels of KGF, HGF, VEGF and Flk-1 in the transfected cells, RT-qPCR and western blot analyses were conducted. The findings (Fig. 5A-C) revealed that, compared with the normal group, the mRNA and protein levels of KGF, HGF, VEGF and 

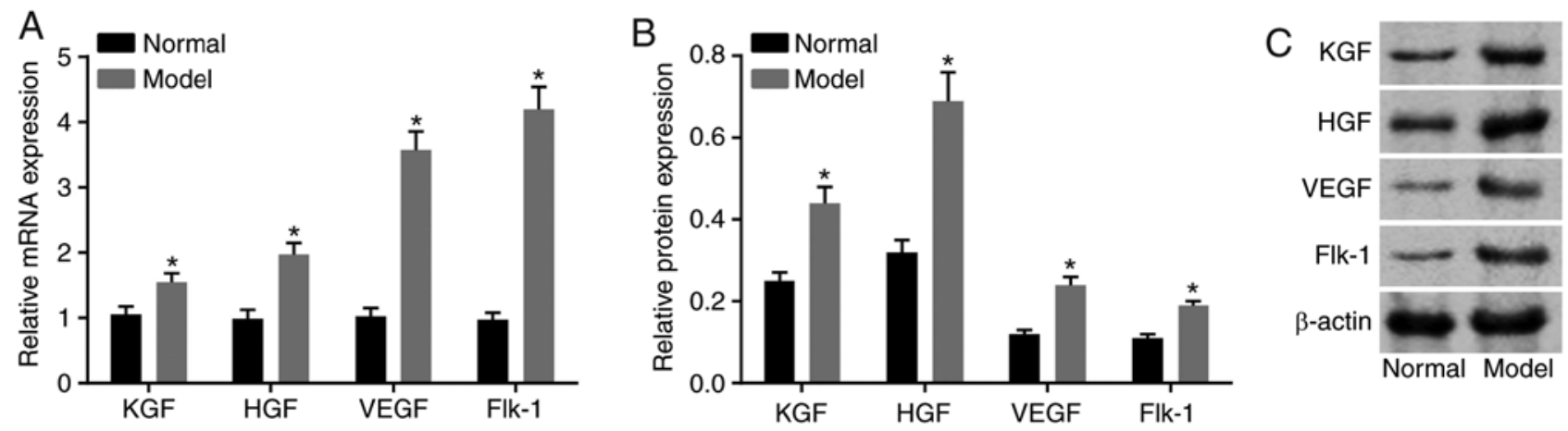

Figure 3. Elevated mRNA and protein levels of KGF, HGF, VEGF and Flk-1 are observed in model rats. (A) Relative mRNA levels of KGF, HGF, VEGF and Flk-1 in the corneal tissues. (B) Relative protein levels of KGF, HGF, VEGF and Flk-1 in the corneal tissues. (C) Gray values of the relative protein bands; ${ }^{*} \mathrm{P}<0.05$, vs. normal group. The mRNA and protein level measurement data are expressed using the mean \pm standard deviation; and the data were normalized to the level in the normal group. Data were analyzed using a one-way analysis of variance, and the experiment was repeated three times independently. KGF, keratinocyte growth factor; HGF, hepatocyte growth factor; VEGF, vascular endothelial growth factor.
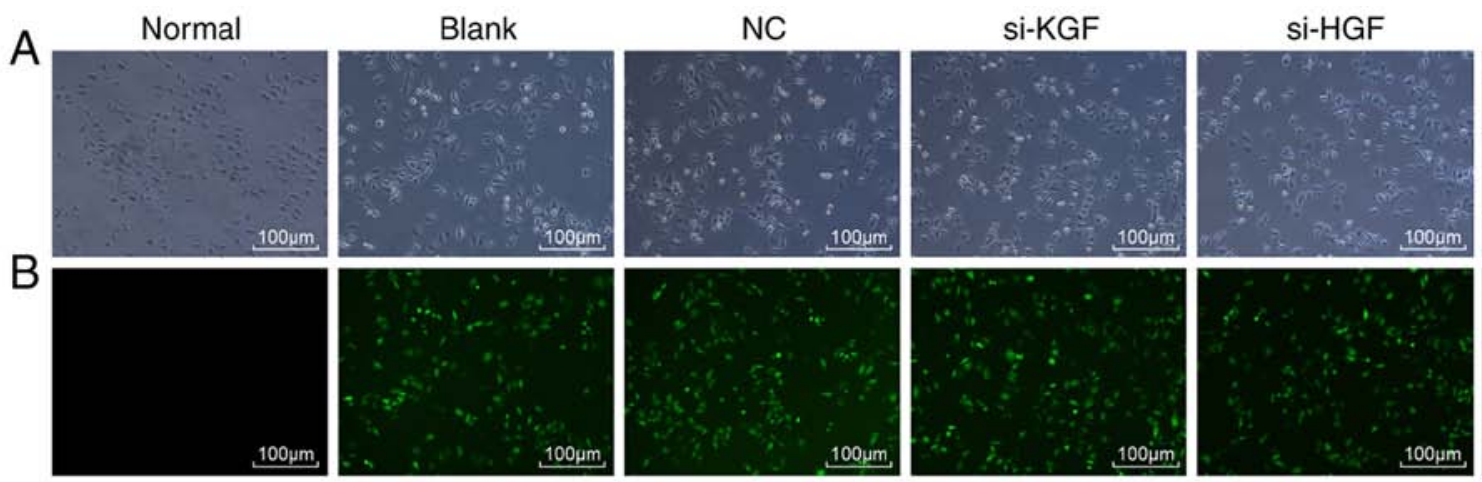

si-HGF/KGF

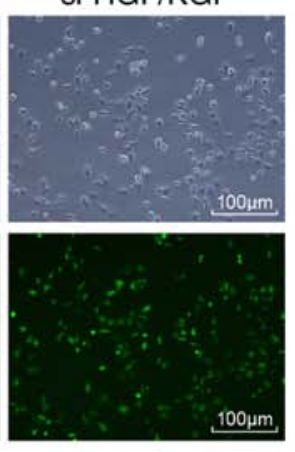

Figure 4. Vectors and sequences are successfully transferred into the corneal epithelial cells of model rats. After $48 \mathrm{~h}$ of lentivirus vector transduction to the corneal epithelial cells, the ratios of the green fluorescence-labeled cells were observed under the fluoroscope (magnification, x100). (A) Images of the cells in each group at a bright-field; scale bar, $100 \mu \mathrm{m}$. (B) Images of the cells under the fluoroscope in each group following $48 \mathrm{~h}$ of transduction; scale bar, $100 \mu \mathrm{m}$. $\mathrm{NC}$, negative control; KGF, fibroblast growth factor; HGF, hepatocyte growth factor; Flk-1, kinase insert domain receptor; si, small interfering RNA.

Flk-1 were significantly increased in the blank, NC, si-KGF, si-HGF and si-HGF/KGF groups (all $\mathrm{P}<0.05$ ). Compared with the blank group, the mRNA and protein levels of VEGF and Flk-1 were notably downregulated in the si-KGF, si-HGF and si-HGF/KGF groups $(\mathrm{P}<0.05)$. The si-KGF and si-HGF groups showed lower mRNA and protein levels of HGF and KGF than the blank group $(\mathrm{P}<0.05)$. The si-HGF/KGF group also exhibited significantly decreased mRNA and protein levels of KGF and HGF $(\mathrm{P}<0.05)$. No significant differences were observed between the NC and blank groups $(\mathrm{P}>0.05)$. The si-HGF/KGF group exhibited lower mRNA and protein levels of VEGF and Flk-1 than the si-KGF group and si-HGF group, with a significant difference $(\mathrm{P}<0.05)$. These results suggested that the gene silencing of both HGF and KGF decreased the expression of KGF, HGF, VEGF and Flk-1.

KGF and HGF gene silencing decreases the proliferation of corneal epithelial cells in the model rats. An MTT assay was conducted to examine cell proliferation in each group, and the results (Fig. 6) demonstrated that the proliferation of the corneal epithelial cells from each group increased as time proceeded $(\mathrm{P}<0.05)$. Compared with the normal group, the other groups showed increased cell proliferation (all $\mathrm{P}<0.05$ ). Compared with the blank group, the si-KGF, si-HGF and
si-HGF/KGF groups exhibited inhibited cell proliferation (all $\mathrm{P}<0.05$ ). No significant differences were observed between the blank and NC groups. Additionally, no significant differences were observed between the si-KGF and si-HGF groups (all $\mathrm{P}>0.05$ ). Compared with the si-KGF and si-HGF groups, the si-HGF/KGF group exhibited decreased cell proliferation (all $\mathrm{P}>0.05$ ). The above results demonstrated that the knockdown of KGF and HGF may downregulate the proliferation ability of corneal epithelial cells in the model rats.

KGF and HGF gene silencing promotes apoptosis of corneal epithelial cells of model rats. To characterize the role of KGF and HGF gene silencing in corneal epithelial cells, with regard to cell cycle and apoptosis, PI staining and Annexin V-FITC/PI double staining were conducted. As shown in Fig. 7A and B, compared with the normal group, the other five groups exhibited decreased ratios of corneal epithelial cells in the G1 phase and increased ratios in the $\mathrm{S}$ phase (all $\mathrm{P}<0.05$ ). Compared with the blank group, the si-KGF, si-HGF and si-HGF/KGF groups exhibited increased cell ratios in the G1 phase and decreased ratios in the $\mathrm{S}$ phase (all $\mathrm{P}<0.05)$. No significant differences were observed in the ratio of the cell distribution in the G1 and S phases between the blank and NC groups $(\mathrm{P}>0.05)$. There were also no notable differences in the ratios 


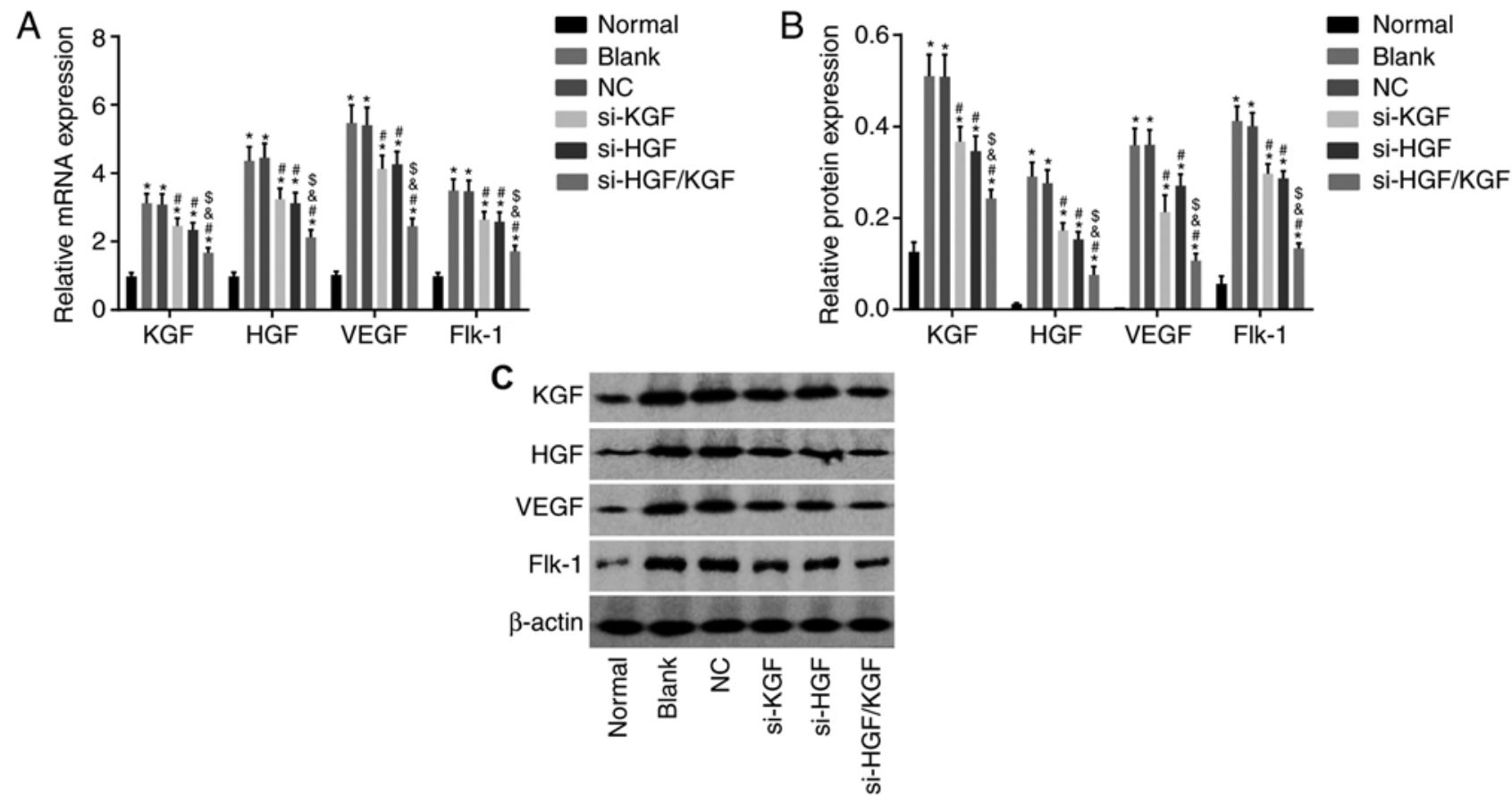

Figure 5. HGF and KGF silencing reduces the levels of KGF, HGF, VEGF and Flk-1 in the corneal epithelial cells of model rats. The mRNA and protein expression levels of KGF, HGF, VEGF and Flk-1 were determined following $48 \mathrm{~h}$ of transduction. (A) Relative mRNA levels of KGF, HGF, VEGF and Flk-1 in each group following $48 \mathrm{~h}$ of transduction, as determined by reverse transcription-quantitative polymerase chain reaction analysis. (B) Relative protein levels of KGF, HGF, VEGF and Flk-1 in each group following $48 \mathrm{~h}$ of transduction. (C) Gray values of the relative protein bands, as determined by western blot analysis; " $\mathrm{P}<0.05$, vs. normal group; ${ }^{\text {}} \mathrm{P}<0.05$, vs. blank group; ${ }^{\circledR} \mathrm{P}<0.05$, vs. si-HGF group; ${ }^{\mathrm{P}} \mathrm{P}<0.05$, vs. si-KGF group. The mRNA and protein levels are measurement data expressed as the mean \pm standard deviation, and data were normalized to the level in the normal group. Data were analyzed using one-way analysis of variance and Tukey's post hoc test. The experiment was repeated three times independently $(n=3)$. NC, negative control; KGF, fibroblast growth factor; HGF, hepatocyte growth factor; VEGF, vascular endothelial growth factor; Flk-1, kinase insert domain receptor; si, small interfering RNA.

of the cell distribution in the G1 and $\mathrm{S}$ phases between the si-KGF and si-HGF groups $(\mathrm{P}>0.05)$. Compared with the si-KGF and si-HGF groups, the si-HGF/KGF group exhibited a significantly increased ratio of corneal epithelial cells in the G1 phase and decreased ratio in the $\mathrm{S}$ phase (all $\mathrm{P}<0.05$ ).

As shown in Fig. 8A and B, Annexin V-FITC/PI double staining demonstrated that the apoptotic rate of the corneal epithelial cells was significantly reduced compared with that of the normal group $(\mathrm{P}<0.05)$. The cell apoptotic rate was notably increased in the si-KGF, si-HGF and si-HGF/KGF groups compared with that in the blank group (all $\mathrm{P}<0.05$ ). No significant difference in apoptotic rate was identified between the blank and NC groups $(\mathrm{P}>0.05)$. There were also no notable differences in the apoptotic rate between the si-KGF and si-HGF groups $(\mathrm{P}>0.05)$. Compared with the si-KGF and si-HGF groups, the apoptotic rate was significantly increased in the si-HGF/KGF group (all $\mathrm{P}<0.05$ ). All the above results demonstrated that KGF and HGF gene silencing promoted the apoptosis of corneal epithelial cells in the model rats.

\section{Discussion}

UVR is identified as the most common cause of radiation injury to the eye (32). UVR evokes photokeratitis, which is accompanied by increased corneal hydration and changes in corneal transparency, leading to increased light absorption (33). Despite their harmfulness, certain microRNAs and genes are found to have potent protective effects on UV-induced corneal damage $(12,13)$. Shi et al stated that peroxiredoxin 6 (PRDX6)

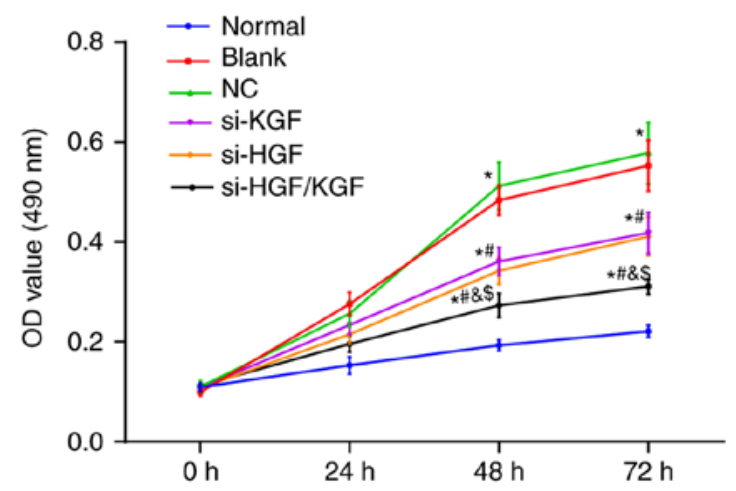

Figure 6. Viabilities of the corneal epithelial cells are reduced by KGF and HGF gene silencing following $48 \mathrm{~h}$ of transduction, as assessed by a 3-(4,5-dimethylthiazol-2-yl)-2,5-diphenyl tetrazolium bromide assay. ${ }^{*} \mathrm{P}<0.05$, vs. normal group; ${ }^{*} \mathrm{P}<0.05$, vs. blank group; ${ }^{\&} \mathrm{P}<0.05$, vs. si-HGF group; ${ }^{~} \mathrm{P}<0.05$, vs. si-KGF group. The experiment was repeated three times. The measurement data are expressed as the mean \pm standard deviation; and data at different time points were analyzed using repeated analysis of variance, and examined using Tukey's test; OD, optical density; NC, negative control; KGF, fibroblast growth factor; HGF, hepatocyte growth factor; Flk-1, kinase insert domain receptor; si, small interfering RNA.

protein can be used to treat UV-induced corneal injury (7), and the present study suggested that silencing of HGF and KGF inhibits the expression of VEGF and its receptor, therefore, assisting in recovery from UV-induced corneal injury. The treatment provided by Shi et al comprised increasing PRDX6 at the protein level and the strategy used in the present study comprised siRNA-mediated gene silencing, both of which 

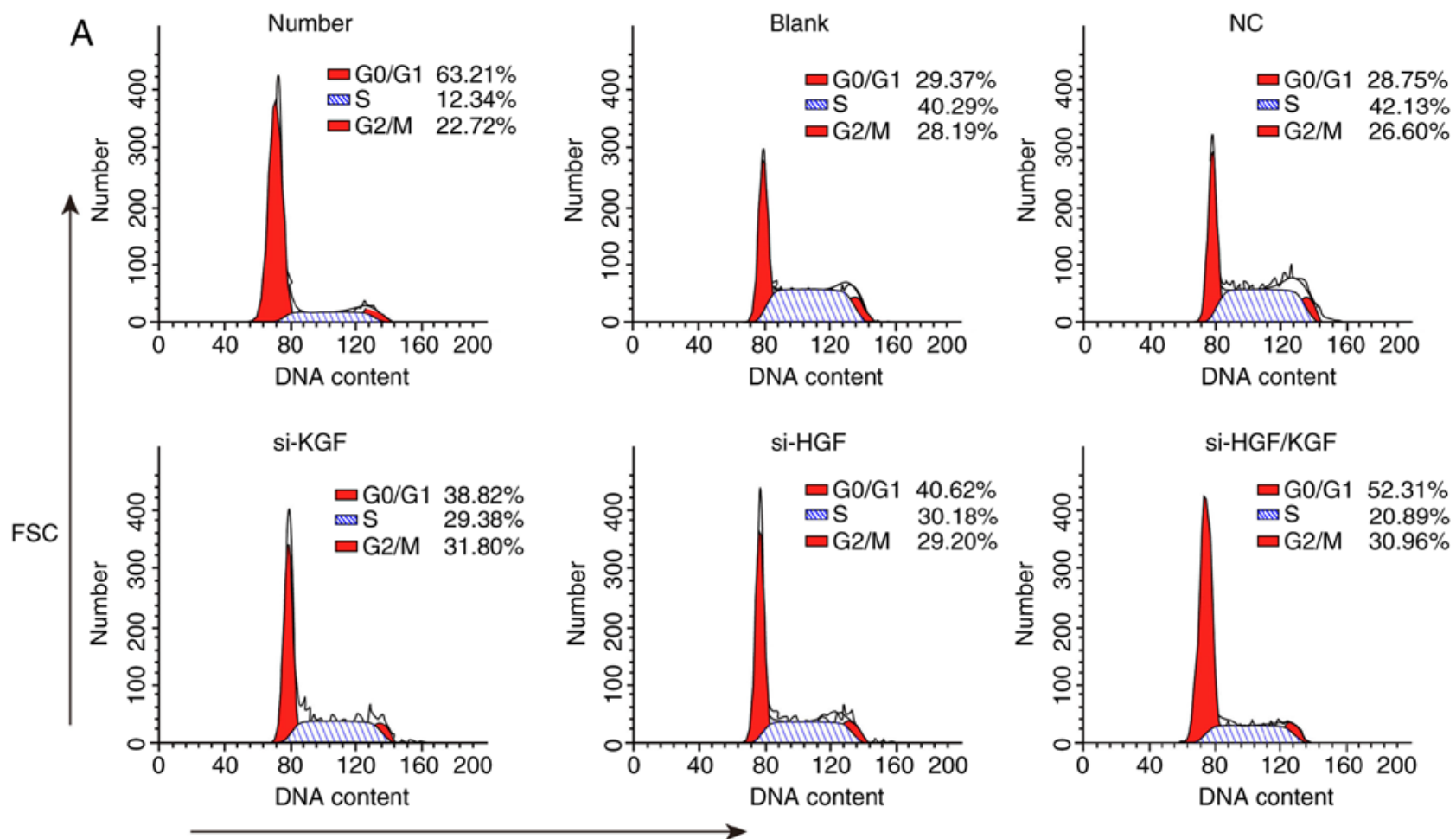

PI

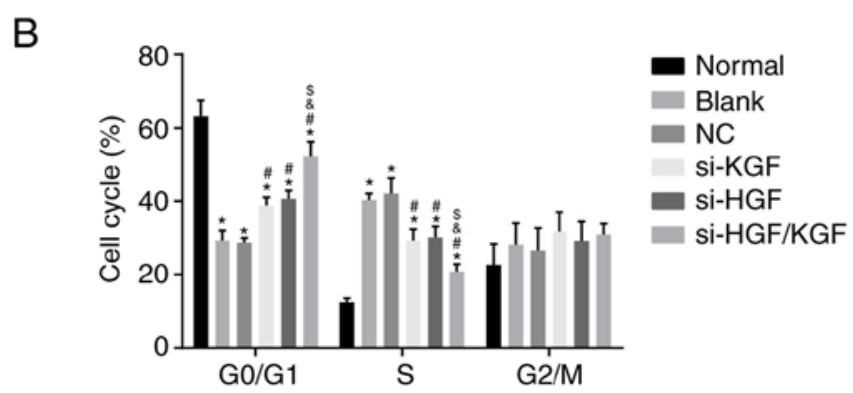

Figure 7. KGF and HGF gene silencing induces cell cycle arrest in corneal epithelial cells. (A) Cell cycle distribution in each group following $48 \mathrm{~h}$ of transduction, as assessed by PI staining. (B) Percentages of cells in $\mathrm{G}_{0} / \mathrm{G}_{1}, \mathrm{~S}$ and $\mathrm{G} 2 / \mathrm{M}$ phase in each group following $48 \mathrm{~h}$ of transduction; " $\mathrm{P}<0.05$, vs. normal group; ${ }^{\#} \mathrm{P}<0.05$, vs. blank group; ${ }^{\&} \mathrm{P}<0.05$, vs. si-HGF group; ${ }^{\$} \mathrm{P}<0.05$, vs. si-KGF group; The experiment was repeated three times independently. The measurement data are expressed as the mean \pm standard deviation and were analyzed using one-way analysis of variance and Tukey's post hoc test. NC, negative control; KGF, fibroblast growth factor; HGF, hepatocyte growth factor; si, small interfering RNA; PI, propidium iodide.

are innovative. In the present study, it was found that HGF and KGF gene silencing possessed the ability to attenuate UVR-induced corneal injury and CNV by suppressing the expression of VEGF and its receptors.

The findings obtained in the present study showed that KGF and HGF were expressed at high levels in the rats with UVR-induced corneal injury and CNV, and the knockdown of KGF and HGF inhibited the proliferation and promoted the apoptosis of corneal epithelial cells. KGF is a well-established mitogen for keratinocytes, which promotes early differentiation and inhibits terminal differentiation of cultured keratinocytes (34). HGF acts by binding to a specific receptor, c-Met, and is reported to promote keratinocyte proliferation and stimulate keratinocyte metalloproteinase production in response to skin injury, migration and proliferation (35). An intact corneal epithelium is essential for maintaining vision and protecting against infection (36). Healing of epithelial wounds in a healthy cornea occurs relatively fast (20). HGF, KGF and their receptors are associated with homeostasis and injury healing in the cornea (14). In addition, it was previously reported that HGF and KGF are expressed in the cornea in response to injury (20). HGF and KGF exhibit a lasting influence on corneal epithelial cell survival and cell growth, and on the regulation of levels of proteins that control apoptosis and cell cycle, which include p53, poly (adenosine diphosphate-ribose) polymerase, retinoblastoma protein, cyclins, CDKs, and cell cycle inhibitor p27kip (17). Both HGF and KGF are important in corneal injury; HGF and KGF promote the proliferation and migration of corneal epithelial cells $(37,38)$.

In the present study, the knockdown of both the HGF and KGF genes prevented corneal epithelial cell proliferation and promoted apoptosis. Podskochy and Fagerholm demonstrated that UV-damage can decrease the number of apoptotic cells, thus, inhibiting cell apoptosis based on a single dose of UVR (30). However, in the present study, cell proliferation and apoptosis were observed following repeated UVR exposure, which has been reported to increase the resistance of corneal stroma cells to apoptosis; therefore, corneal stroma 
A
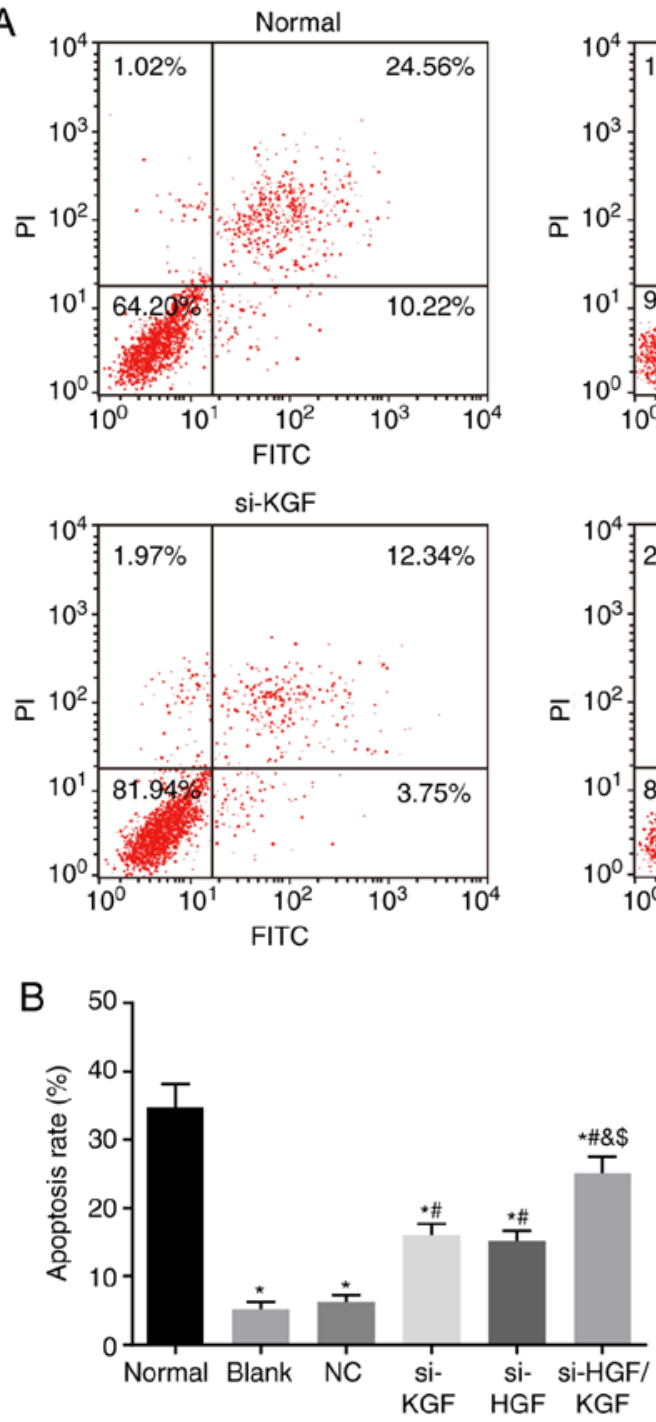
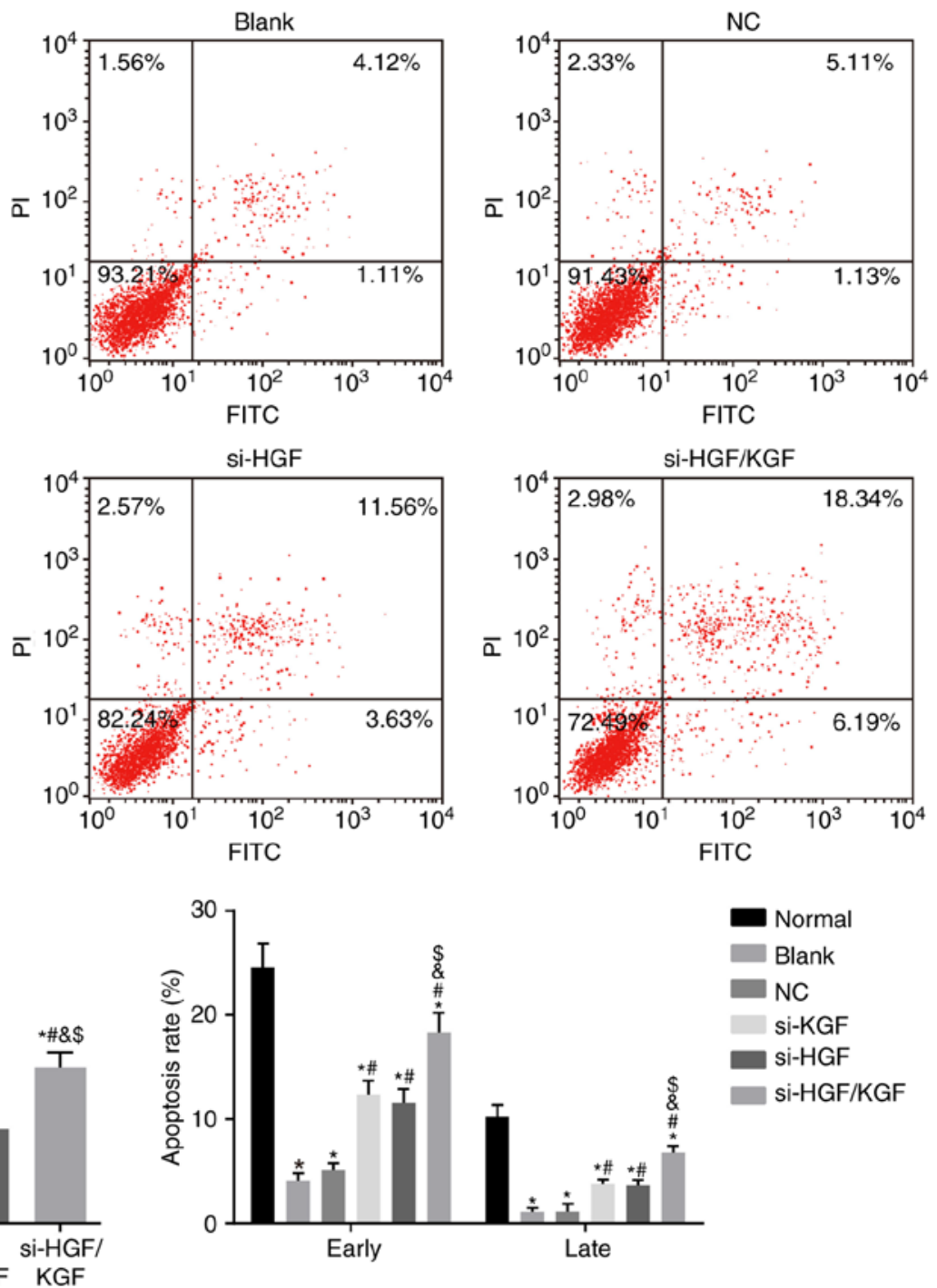

Figure 8. KGF and HGF gene silencing promotes apoptosis of corneal epithelial cells. (A) Flow chart of cell apoptosis in each group following 48 h of transduction, as detected by Annexin V-FITC/PI double staining. (B) Apoptotic cell rates in each group. ${ }^{*} \mathrm{P}<0.05$, vs. normal group; ${ }^{\text {"}} \mathrm{P}<0.05$, vs. blank group; ${ }^{\circledR} \mathrm{P}<0.05$, vs. si-HGF group; ${ }^{\$} \mathrm{P}<0.05$, vs. si-KGF group; The experiment was repeated three times. The measurement data are expressed as the mean \pm standard deviation and were analyzed using a one-way analysis of variance and Tukey's post hoc test. NC, negative control; KGF, fibroblast growth factor; HGF, hepatocyte growth factor; Flk-1, kinase insert domain receptor; si, small interfering RNA; FITC/PI, fluorescein isothiocyanate/propidium iodide.

cells exhibit apoptosis resistance. Acute UVB exposure leads to photokeratitis and triggers the apoptosis of corneal cells (6). Prolonged eye exposure to UV induces photokeratitis, which affects all tissues of the cornea (39) and induces the expression of various inflammatory agents, including nuclear factor- $\kappa$-light chain enhancer of activated $B$ cells $(N F-\kappa B)$ and prostaglandin E2 (40). Photokeratitis is generally associated with lost or injured corneal epithelial cells due to natural and artificial UVR $(33,41)$. UV exposure affects all tissues of the cornea, and causes apoptosis of corneal cells through direct cell membrane damage, DNA damage and ROS induction as a result of an inflammatory reaction (39). Under UVR, corneal damage is mediated through increased levels of lipid peroxidation products (malondialdehyde and 4-hydroxynonenal), inflammatory mediators (NF- $\kappa \mathrm{B}$ and cyclooxygenase-2), cell death factors (Fas receptor) and matrix metalloproteinases (MMP-9 and MMP-2) (42). Consistently, the present study found that excessive exposure to UVR in the cornea may induce photokeratitis, damage to the epithelium, corneal opacities, edema and CNV.
Corneal transparency and vascularity are important for maintaining proper optical performance of the cornea (43). $\mathrm{CNV}$ involves the development of new vascular structures in areas that were previously avascular (44). CNV can be induced by infection, inflammation, degeneration or delayed wound-healing disorders in the ocular surfaces (45). VEGF, a potent angiogenic stimulator, promotes proliferation, migration, proteolytic activity and capillary tube formation by endothelial cells (46). During CNV, VEGF is expressed at high levels in the vascular endothelial cells of the limbal vessels and in newly formed vessels in the stroma, but its expression is weak in keratocytes (47). Correspondingly, VEGF is significantly increased in the vascularized cornea compared with the normal cornea (47). It was previously reported that VEGF is involved in the process of UVR-induced CNV (7). The expression of VEGF is elevated by HGF and KGF, indicating their involvement in the regulation of angiogenesis $(48,49)$. In the present study, the protein level of VEGF was significantly reduced by the knockdown of both HGF and KGF. 
It has been shown that corneal injury can lead to the inflammatory response and damage to sensory nerves $(50,51)$. However, the present study only focused on the effects of $\mathrm{HGF} / \mathrm{KGF}$ in VEGF and its receptors in corneal epithelial cells, rather than the biological function of corneal nerves. KGF and HGF can influence the proliferation and migration of epithelial cells by activating the p38/extracellular signal-regulated kinase 1/2 signaling pathway $(37,52)$. Therefore, silencing of KGF or HGF alone can suppress cell proliferation and migration, and silencing of both leads to the same effects. In the present study, HGF silencing reduced the expression of $\mathrm{KGF}$, and KGF silencing reduced the expression of HGF. Interleukin (IL)- $1 \beta$ and IL- $1 \alpha$ have been reported to upregulate the expression of HGF and KGF (53), based on which it was hypothesized that the silencing of HGF or KGF alone not only inhibits corneal epithelial cell proliferation, but also downregulates the expression of cell-secreted IL-1 $\beta$ and IL- $1 \alpha$, thus indirectly influencing the promotive effects of IL-1 $\beta$ and IL-1 $\alpha$ on KGF/HGF. As a result, HGF gene silencing may lead to decreased KGF, and KGF gene silencing may lead to decreased HGF. Although the present study found that HGF may interact with KGF in UVR-induced CNV, the interaction between HGF and KGF remains to be fully elucidated. Confirmation with more reliable data is required in subsequent investigations. In addition, the specific channel of small molecules and siRNA entering corneal cells, and whether they causing injury to other organs with involvement of the circulatory system in humans remains to be elucidated. Therefore, rat model established in the present study is not applicable to humans, and requires attention in future investigations. Despite this, the findings of the present study support a theoretical basis for a novel target in corneal wound healing following UVR exposure.

\section{Acknowledgements}

Not applicable.

\section{Funding}

The present study was supported by the Shanxi Scholarship Council of China (grant no. 2016-062); the Fund Program for the Scientific Activities of Selected Returned Overseas Professionals in Shanxi Province (grant no. 2017-144) and the Fund Program for Doctor of Shanxi Medical University (grant no. BS201712).

\section{Availability of data and materials}

The datasets used and/or analyzed during the current study are available from the corresponding author on reasonable request.

\section{Authors' contributions}

Conception and design: MH, TH, YW, YHW, WSQ, LZD and CQZ; analysis and interpretation: $\mathrm{MH}, \mathrm{TH}, \mathrm{YW}, \mathrm{YHW}$, WSQ, LZD and CQZ; data collection: $\mathrm{MH}, \mathrm{TH}, \mathrm{YW}, \mathrm{YHW}$, WSQ, LZD and CQZ; manuscript preparation: $\mathrm{MH}, \mathrm{TH}$ and YW; statistical analysis: LZD and CQZ; critical revision of the manuscript: MH, TH, YW, YHW, WSQ, LZD and CQZ; final approval of the manuscript: $\mathrm{MH}, \mathrm{TH}, \mathrm{YW}, \mathrm{YHW}, \mathrm{WSQ}, \mathrm{LZD}$ and CQZ. All authors read and approved the final manuscript.

\section{Ethics approval and consent to participate}

This study protocol was approved by the Animal Ethics Committee of the Second Hospital, Shanxi Medical University. All animal experiments were performed in line with the approval of the Guide for the Care and Use of Laboratory Animal by International Committees.

\section{Patient consent for publication}

Not applicable.

\section{Competing interests}

The authors declare that they have no competing interests.

\section{References}

1. Tsai CF, Lu FJ and Hsu YW: Protective effects of Dunaliella salina - a carotenoids-rich alga-against ultraviolet B-induced corneal oxidative damage in mice. Mol Vis 18: 1540-1547, 2012.

2. Green PG, Alvarez P and Levine JD: Topical tetrodotoxin attenuates photophobia induced by corneal injury in the rat. J Pain 16: 881-886, 2015.

3. Couture C, Zaniolo K, Carrier P, Lake J, Patenaude J, Germain L and Guérin SL: The tissue-engineered human cornea as a model to study expression of matrix metalloproteinases during corneal wound healing. Biomaterials 78: 86-101, 2016.

4. Lu Y, Feng J, Yang L, Tang H, Jin J and Xu X: Anti-inflammatory effects of a synthetic peptide derived from pigment epitheliumderived factor on $\mathrm{H}_{2} \mathrm{O}_{2}$-induced corneal injury in vitro. Chin Med J (Engl) 127: 1438-1444, 2014.

5. Lennikov A, Kitaichi N, Fukase R, Murata M, Noda K, Ando R, Ohguchi T, Kawakita T, Ohno S and Ishida S: Amelioration of ultraviolet-induced photokeratitis in mice treated with astaxanthin eye drops. Mol Vis 18: 455-464, 2012.

6. Lennikov A, Kitaichi N, Kase S, Noda K, Horie Y, Nakai A, Ohno $S$ and Ishida S: Induction of heat shock protein 70 ameliorates ultraviolet-induced photokeratitis in mice. Int J Mol Sci 14: 2175-2189, 2013

7. Shi H, Yu HJ, Wang HY, Wang WT, Jin SH, Zhu P, Li SJ, Rong CT and Li JY: Topical administration of peroxiredoxin-6 on the cornea suppresses inflammation and neovascularization induced by ultraviolet radiation. Invest Ophthalmol Vis Sci 53: 8016-8028, 2012.

8. Gu XJ, Liu X, Chen YY,Zhao Y, Xu M, Han XJ, Liu QP, Yi JL and $\mathrm{Li}$ JM: Involvement of NADPH oxidases in alkali burn-induced corneal injury. Int J Mol Med 38: 75-82, 2016.

9. Chen MH, Tsai CF, Hsu YW and Lu FJ: Epigallocatechin gallate eye drops protect against ultraviolet B-induced corneal oxidative damage in mice. Mol Vis 20: 153-162, 2014.

10. Zuclich JA: Ultraviolet-induced photochemical damage in ocular tissues. Health Phys 56: 671-682, 1989.

11. Golu A, Gheorghişor I, Bălăşoiu AT, Baltă F, Osiac E, Mogoantă $\mathrm{L}$ and Bold A: The effect of ultraviolet radiation on the cornea-experimental study. Rom J Morphol Embryol 54: 1115-1120, 2013.

12. Seo M, Choi JS, Rho CR, Joo CK and Lee SK: MicroRNA miR-466 inhibits Lymphangiogenesis by targeting prospero-related homeobox 1 in the alkali burn corneal injury model. J Biomed Sci 22: 3, 2015.

13. Chu PH, Yeh LK, Lin HC, Jung SM, Ma DH, Wang IJ, Wu HH, Shiu TF and Chen J: Deletion of the FHL2 gene attenuating neovascularization after corneal injury. Invest Ophthalmol Vis Sci 49: 5314-5318, 2008

14. Wilson SE, Chen L, Mohan RR, Liang Q and Liu J: Expression of HGF, KGF, EGF and receptor messenger RNAs following corneal epithelial wounding. Exp Eye Res 68: 377-397, 1999.

15. Matsumoto K, Funakoshi H, Takahashi H and Sakai K: HGF-Met pathway in regeneration and drug discovery. Biomedicines 2 : 275-300, 2014.

16. Boccaccio C, Andò M, Tamagnone L, Bardelli A, Michieli P, Battistini $C$ and Comoglio PM: Induction of epithelial tubules by growth factor HGF depends on the STAT pathway. Nature 391: 285-288, 1998. 
17. Finch PW, Rubin JS, Miki T, Ron D and Aaronson SA: Human KGF is FGF-related with properties of a paracrine effector of epithelial cell growth. Science 245: 752-755, 1989.

18. Cheng CC, Wang DY, Kao MH and Chen JK: The growthpromoting effect of KGF on limbal epithelial cells is mediated by upregulation of DeltaNp63alpha through the p38 pathway. J Cell Sci 122: 4473-4480, 2009.

19. McBain VA, Forrester JV and McCaig CD: HGF, MAPK, and a small physiological electric field interact during corneal epithelial cell migration. Invest Ophthalmol Vis Sci 44: 540-547, 2003

20. Chandrasekher G, Pothula S, Maharaj G and Bazan HE: Differential effects of hepatocyte growth factor and keratinocyte growth factor on corneal epithelial cell cycle protein expression, cell survival, and growth. Mol Vis 20: 24-37, 2014.

21. Li X, Zhou Q, Hanus J, Anderson C, Zhang H, Dellinger M, Brekken $\mathrm{R}$ and Wang $\mathrm{S}$ : Inhibition of multiple pathogenic pathways by histone deacetylase inhibitor SAHA in a corneal alkali-burn injury model. Mol Pharm 10: 307-318, 2013.

22. Dvorak HF, Nagy JA, Feng D, Brown LF and Dvorak AM Vascular permeability factor/vascular endothelial growth factor and the significance of microvascular hyperpermeability in angiogenesis. Curr Top Microbiol Immunol 237: 97-132, 1999.

23. Das P, Pereira JA, Chaklader M, Law A, Bagchi K, Bhaduri G, Chaudhuri S and Law S: Phenotypic alteration of limbal niche-associated limbal epithelial stem cell deficiency by ultraviolet-B exposure-induced phototoxicity in mice. Biochem Cell Biol 91: 165-175, 2013.

24. Fujihara T, Nagano T, Endo K, Nakamura M and Nakata K: Lactoferrin protects against UV-B irradiation-induced corneal epithelial damage in rats. Cornea 19: 207-211, 2000.

25. Dickey JB, Cassidy EM and Bouchard CS: Periocular FK-506 delays allograft rejection in rat penetrating keratoplasty. Cornea 12: 204-207, 1993.

26. Du S, Han B, Li K, Zhang X, Sha X and Gao L: Lycium barbarum polysaccharides protect rat corneal epithelial cells against ultraviolet $\mathrm{B}$-induced apoptosis by attenuating the mitochondrial pathway and inhibiting JNK phosphorylation. Biomed Res Int 2017: 5806832, 2017.

27. Schefe JH, Lehmann KE, Buschmann IR, Unger $T$ and Funke-Kaiser H: Quantitative real-time RT-PCR data analysis: Current concepts and the novel 'gene expression's CT difference' formula. J Mol Med (Berl) 84: 901-910, 2006.

28. Wood JC: Principles of gating. Curr Protoc Cytom Chapter 1: Unit 18,2001

29. Jose JG and Pitts DG: Wavelength dependency of cataracts in albino mice following chronic exposure. Exp Eye Res 41: $545-563,1985$

30. Podskochy A and Fagerholm P: Repeated UVR exposures cause keratocyte resistance to apoptosis and hyaluronan accumulation in the rabbit cornea. Acta Ophthalmol Scand 79: 603-608, 2001

31. Ibrahim OM, Kojima T, Wakamatsu TH, Dogru M, Matsumoto Y, Ogawa Y, Ogawa J, Negishi K, Shimazaki J, Sakamoto Y, et al: Corneal and retinal effects of ultraviolet-B exposure in a soft contact lens mouse model. Invest Ophthalmol Vis Sci 53 2403-2413, 2012.

32. Pauloin T, Dutot M, Joly F, Warnet JM and Rat P: High molecular weight hyaluronan decreases UVB-induced apoptosis and inflammation in human epithelial corneal cells. Mol Vis 15 : 577-583, 2009

33. Cejka C, Ardan T, Sirc J, Michálek J, Beneš J, Brůnová B and Rosina J: Hydration and transparency of the rabbit cornea irradiated with UVB-doses of $0.25 \mathrm{~J} / \mathrm{cm}(2)$ and $0.5 \mathrm{~J} / \mathrm{cm}(2)$ compared with equivalent UVB radiation exposure reaching the human cornea from sunlight. Curr Eye Res 36: 607-613, 2011

34. Marchese C, Rubin J, Ron D, Faggioni A, Torrisi MR, Messina A, Frati L and Aaronson SA: Human keratinocyte growth factor activity on proliferation and differentiation of human keratinocytes: Differentiation response distinguishes KGF from EGF family. J Cell Physiol 144: 326-332, 1990.

35. Weidner KM, Behrens J, Vandekerckhove J and Birchmeier W: Scatter factor: Molecular characteristics and effect on the invasiveness of epithelial cells. J Cell Biol 111: 2097-2108, 1990.
36. Azfar MF, Khan MF and Alzeer AH: Protocolized eye care prevents corneal complications in ventilated patients in a medical intensive care unit. Saudi J Anaesth 7: 33-36, 2013.

37. Sharma GD, He J and Bazan HE: p38 and ERK1/2 coordinate cellular migration and proliferation in epithelial wound healing: Evidence of cross-talk activation between MAP kinase cascades. J Biol Chem 278: 21989-21997, 2003.

38. Chen TC and Chang SW: Effect of mitomycin C on IL-1R expression, IL-1-related hepatocyte growth factor secretion and corneal epithelial cell migration. Invest Ophthalmol Vis Sci 51: 1389-1396, 2010.

39. Cullen AP, Chou BR, Hall MG and Jany SE: Ultraviolet-B damages corneal endothelium. Am J Optom Physiol Opt 61: 473-478, 1984

40. Schein OD: Phototoxicity and the cornea. J Natl Med Assoc 84: 579-583, 1992.

41. Mangan MS, Arici C, Atalay E, Tanyildiz B and Orucoglu F: Four cases of pediatric photokeratitis present to the emergency department after watching the same theater show. Turk J Ophthalmol 45: 226-228, 2015.

42. Liou JC, Teng MC, Tsai YS, Lin EC and Chen BY: UV-blocking spectacle lens protects against UV-induced decline of visual performance. Mol Vis 21: 846-856, 2015.

43. Ambati BK, Nozaki M, Singh N, Takeda A, Jani PD, Suthar T, Albuquerque RJ, Richter E, Sakurai E, Newcomb MT, et al: Corneal avascularity is due to soluble VEGF receptor-1. Nature 443: 993-997, 2006.

44. Azar DT: Corneal angiogenic privilege: Angiogenic and antiangiogenic factors in corneal avascularity, vasculogenesis, and wound healing (an American Ophthalmological Society thesis). Trans Am Ophthalmol Soc 104: 264-302, 2006.

45. Zhang SX and Ma JX: Ocular neovascularization: Implication of endogenous angiogenic inhibitors and potential therapy. Prog Retin Eye Res 26: 1-37, 2007.

46. Dvorak HF, Brown LF, Detmar M and Dvorak AM: Vascular permeability factor/vascular endothelial growth factor, microvascular hyperpermeability, and angiogenesis. Am J Pathol 146: 1029-1039, 1995

47. Philipp W, Speicher L and Humpel C: Expression of vascular endothelial growth factor and its receptors in inflamed and vascularized human corneas. Invest Ophthalmol vis Sci 41: 2514-2522, 2000

48. Matsumura A, Kubota T, Taiyoh H, Fujiwara H, Okamoto K, Ichikawa D, Shiozaki A, Komatsu S, Nakanishi M, Kuriu Y, et al: HGF regulates VEGF expression via the c-Met receptor downstream pathways, PI3K/Akt, MAPK and STAT3, in CT26 murine cells. Int J Oncol 42: 535-542, 2013.

49. Narita K, Fujii T, Ishiwata T, Yamamoto T, Kawamoto $Y$, Kawahara K, Nakazawa N and Naito Z: Keratinocyte growth factor induces vascular endothelial growth factor-A expression in colorectal cancer cells. Int J Oncol 34: 355-360, 2009.

50. Pal-Ghosh S, Tadvalkar G and Stepp MA: Alterations in corneal sensory nerves during homeostasis, aging, and after injury in mice lacking the heparan sulfate proteoglycan syndecan-1. Invest Ophthalmol Vis Sci 58: 4959-4975, 2017.

51. Pan Z,Fukuoka S, Karagianni N, Guaiquil VH and Rosenblatt MI: Vascular endothelial growth factor promotes anatomical and functional recovery of injured peripheral nerves in the avascular cornea. FASEB J 27: 2756-2767, 2013

52. Chandrasekher G, Kakazu AH and Bazan HE: HGF- and KGF-induced activation of PI-3K/p70 s6 kinase pathway in corneal epithelial cells: Its relevance in wound healing. Exp Eye Res 73: 191-202, 2001.

53. Weng J, Mohan RR, Li Q and Wilson SE: IL-1 upregulates keratinocyte growth factor and hepatocyte growth factor mRNA and protein production by cultured stromal fibroblast cells: Interleukin-1 beta expression in the cornea. Cornea 16: 465-471, 1997. 